\title{
A Study on Adolescent Students' Levels of Hopelessness, Loneliness and Self-Esteem: A Sample from Turkey
}

\author{
Medine Baran \\ Dicle University, Department of Physics Education, Diyarbakır, Turkey \\ medabaran@gmail.com (Coresspending Author) \\ Mukadder Baran \\ Hakkari University Department of Science education, Hakkari, Turkey \\ felekbaran@hotmail.com \\ Abdulkadir Maskan \\ Dicle University department of Physics education, Diyarbakır, Turkey \\ akmaskan@gmail.com
}

\section{Doi:10.5901/mjss.2015.v6n2s1p341}

\begin{abstract}
The purpose of the present study was to determine high school students' levels of hopelessness, self-esteem and loneliness and to examine the relationship between some variables. The research sample included 403 students (Female: 234, Male: 169). In the study, Beck's hopelessness scale, Rosenberg's self-esteem scale, Ucla's loneliness scale and demographic information questionnaire were used as the data collection tool. The data were analyzed using t-test, Anova and descriptive analysis. The findings obtained revealed that there were meaningful differences and correlations between scores of hopelessness, loneliness and self-esteem of the students in the study with respect to their types of schools, gender, family's income. Depending on these findings, it is suggested that the students who have to struggle with various difficulties and problems during the period of adolescence, should be provided with psychological support both at schools and in various social units.
\end{abstract}

Keywords: Adolescent students, hopelessness, loneliness, self esteem, demographic informations.

\section{Introduction}

In this era, there are a number of factors influencing the life style of individuals, their viewpoints and their current and future positions. These can be called environmental and personal factors, and they have strong connections with each other. It is thought that what individuals experience psychologically influences their whole lives. The fact that social, cultural and financial conditions are today in rapid change makes adolescence more difficult, which is an unsteady period in an individual's psychosocial development (Özmen et. al., 2008). The psychological conflicts experienced especially in this period are also likely to lead to breakdowns in the adolescents" psychology. Eccless et. al. (1993) define adolescence as a transition period involving psychological, cognitive and emotional changes as this period includes puberty, identity seeking, need for intimate relationships, cognitive development, sexual development and efforts to become psychologically independent of the family. Studies conducted demonstrate that such cases of adolescents as self-esteem, hopelessness and loneliness are important for individuals to lead a healthy life (Nordin et. al., 2009; Çeçen, 2008; Erözkan, 2011). Individual's self-esteem in this period, their hope for their lives and their communication with their social environment are important for their current lives as well as for their future lives.

According to Yörüköğlu (1998), self-esteem refers to a an individual's positive psychological state which, without considering oneself as inferior or superior, involves self-confidence, satisfaction with the self and finding oneself worth admiring. According to Coleman \& Hendry (1990), individuals with high levels of self-esteem tend to have a higher possibility to become much happier, healthier, more productive and more successful, to be able to overcome difficulties, to sleep well at nights, to have less possibility to have the ulcer disease, to be open in their social relationships and to resist their peers' pressure, while individuals with lower levels of self-esteem tend to have anxious, pessimistic and 
negative views about their future and become unsuccessful. Hopelessness could be defined as the negative thoughts that individuals have for future.

Similarly, hopelessness influences human life negatively. Individuals with a tendency towards hopelessness have a cognitive set for future, and this cognitive set repeatedly tells them that there is no good future possible for them (Erozkan, 2011). Studies reported in related literature point out that hopelessness could cause adolescents to give damage to themselves or to others (Rutter \& Behrendt, 2004; Lai Kwok \& Shek, 2010; Bolland, Mccallum, Lian, Bailey \& Rowan, 2001).

Loneliness, one type in psychological life with its negative reflections upon human life, refers to feeling oneself lonely and helpless. Peplau and Perlman (1982) perceive loneliness as one basis of human relations and define it as a feeling caused by the failure of an individual's current relationships to meet his or her related expectations (cited in Eskin, 2001). Similar to such feelings as depression and anxiety, loneliness is a situation that leads to negative effects. Lonely individuals have fewer expectations and hopes regarding life than individuals who are not lonely. In literature, there are findings demonstrating that loneliness increases individuals' satisfaction with life (Goodwin, Cook and Yung, 200; Moore and Schultz, 1983; Kapıkıran and Yağcı, 2012). In the period of adolescence, individuals casted out or left alone by their social environments are more likely to experience psychological breakdowns and to feel distress than adults.

In this respect, it will be beneficial to determine adolescents' levels of self-esteem, hopelessness and loneliness and the possible environmental factors and to take the necessary precautions. In this way, there will be healthier societies in future.

\section{Significance of the Study}

In today's developing world, the psychological problems of especially adolescents are gradually increasing. In literature, there is no research conducted to investigate adolescents' levels of loneliness, hopelessness and self-esteem all together - which influence their personality development - and to examine the interaction in-between. In developing countries like Turkey as well as in all parts of the world where there are young people, it is fairly important to conduct such studies and to take the necessary measures in line with the results of these studies. The results obtained in such studies are thought to be important for understanding the problems and difficulties experienced by adolescents.

\section{Problem}

In the present study, the purpose was to determine high school $1^{\text {st }}$ grade, $2^{\text {nd }}$ grade and $3^{\text {rd }}$ grade students' levels of selfesteem, hopelessness and loneliness, to examine the relationships between these variables and to investigate how their levels of self-esteem, hopelessness and loneliness were influenced by their demographic backgrounds.

\section{Method}

\subsection{Participants}

The participants in the study were $4031^{\text {st }}$ grade, $2^{\text {nd }}$ grade and $3^{\text {rd }}$ grade students from different types of secondary schools (M:169, F:234) in the city center of Hakkari. The study included Science High School ( $n=204)$, which admits academically successful students with high scores in a placement test executed for student selection for the school; Anatolian High School $(n=41)$, which admits students with lower scores in the placement test; Regular High School $(n=57)$, which does not require any specific scores from the placement test; and the Vocational School for Girls ( $n=101)$, which gives vocational education only to female students. In the study, the schools were determined with the availability sampling method. 
Table 1. Frequencies of the Demographic Backgrounds of the Participating Students

\begin{tabular}{|c|c|c|}
\hline Variable & Groups & $\mathrm{f}$ \\
\hline \multirow{3}{*}{ Class-grade } & 1 & 148 \\
& 2 & 124 \\
& 3 & 131 \\
\hline \multirow{4}{*}{ Age } & 14 & 15 \\
& 15 & 95 \\
& 16 & 129 \\
Father's educational background & 17 & 130 \\
& 18 & 34 \\
\hline \multirow{4}{*}{ Mother's educational background } & None of them & 62 \\
& Elementary school & 150 \\
& Secondary school & 49 \\
& High school & 90 \\
& University & 52 \\
\hline \multirow{3}{*}{ Number of siblings } & None of them & 185 \\
& Elementary school & 142 \\
& Secondary school & 32 \\
& High school & 40 \\
& University & 4 \\
\hline \multirow{3}{*}{ Financial State } & $1-3$ & 79 \\
& $4-6$ & 158 \\
& $7-9$ & 122 \\
& 10 or over & 44 \\
\hline & Below the minimum living wage (658 TLS) & 138 \\
& Between the minimum living wage and 1000 TLs & 115 \\
& 1000-2000 TLs & 109 \\
& 2000TLs-3000Tls & 26 \\
& 3000TLs or more & 15 \\
\hline
\end{tabular}

\subsection{Data Collection Tools}

In the study, Rosenberg Self-Esteem Scale, UCLA Loneliness Scale, Beck Hopelessness Scale and a personal information questionnaire were used as the data collection tool.

Rosenberg Self-Esteem Scale developed by Rosenberg (1963). In this study, Cronbach's alpha reliability coefficient was calculated as .78. The scale included 10 items. The scale ranges from $0-30$. The scores between 15 and 25 are within normal range, and those below 15 suggest low self-esteem (http://www.wwnorton.com/college/psych/ psychsci/media/ rosenberg.htm).

All the items of the UCLA Loneliness Scale developed by Russell, Peplau and Ferguson (1978) to measure individuals' levels of loneliness (University of California Los Angeles Loneliness Scale) included negative statements. However, thinking that this led to a systematic bias, Russel, Peplau and Cotrana (1980) revised the scale and transformed it into a scale made up of items half of which included positive statements and the other half of which included negative statements (Demir, 1989). The R-UCLA Loneliness Scale was made up of 20 items. The highest score to be produced by the scale was 80 , and the lowest to be produced was 20 . The higher score refers to a high level of loneliness (Demir, 1989). In this study, Cronbach's alpha reliability coefficient of the UCLA Loneliness Scale was calculated as .79.

Beck Hopelessness Scale is a 20-item scale producing a score of 0 or a score of 1 . It was developed by Beck and his colleagues (1974). In this study, Cronbach's alpha reliability coefficient was calculated as .81. In the scale including positive and negative statements regarding future, individuals are asked to mark "Yes" for the statements which appeal to them and "No" for those which do not. The score range is 0-20. The scores of 0-3: Minimal; 4-8: Mild; 9-14: Moderate; and 15-20: Severe (Beck \& Steer, 1988).

The personal information form was used as a data collection tool to determine certain demographic backgrounds of the students. The form was made up of 8 main headings. These headings were the type of the schools the students were attending, their class-grades, gender, ages, number of their siblings, their parents' educational backgrounds and their monthly family income. 


\subsection{Data Analysis}

The data collected at the end of the study were analyzed with the correlation analysis method, independent groups t-test, Tukey, ANOVA and descriptive analysis.

\section{Findings}

The findings of the present study were obtained via the statistical analyses of the research data collected with Beck Hopelessness Scale, Rosenberg Self-Esteem Scale, UCLA Loneliness Scale and the Personal Information Questionnaire applied to the high school students who were in the period of adolescence.

Table 2. Analysis Results of The Frequencies Regarding The High School Students' Levels of Self-Esteem

\begin{tabular}{|c|c|}
\hline Self-Esteem Score & Frequency \\
\hline Below 15 & 87 \\
\hline 15-25 & 280 \\
\hline Over 25 & 36 \\
\hline
\end{tabular}

When Table 2 is examined, it is seen that approximately $21,6 \%$ of the participating students had low self-esteem scores; that $69,5 \%$ them had a normal level of self-esteem; and that $8,9 \%$ of them had a high level of self-esteem.

Table 3. Analysis Results of The Frequencies Regarding the High School Students' Levels of Loneliness

\begin{tabular}{|c|c|}
\hline Loneliness Score & Frequency \\
\hline $20-30$ & 63 \\
\hline $31-40$ & 149 \\
\hline $41-50$ & 128 \\
\hline $51-60$ & 53 \\
\hline $61-70$ & 9 \\
\hline $71-80$ & 1 \\
\hline
\end{tabular}

Table 3 demonstrates that around $52,6 \%$ of the study group students had lower scores than the mean score of 40 and that $47,4 \%$ of them had higher scores than the mean score of 40 .

Table 4. Analysis Results of The Frequencies Regarding The High School Students' Levels of Hopelessness

\begin{tabular}{|c|c|}
\hline Hopelessness Score & Frequency \\
\hline $0-3$ & 137 \\
\hline $4-8$ & 166 \\
\hline $9-14$ & 81 \\
\hline $15-20$ & 19 \\
\hline
\end{tabular}

When the results in Table 4 are examined, it is seen that approximately $34 \%$ of the students had a minimal level of Ioneliness; that $41,2 \%$ of them had a mild level of loneliness; that $20,1 \%$ of them had a moderate level of loneliness; and that $4,7 \%$ of them had a severe level of loneliness, which could be considered to be an alarming level. 
Table 5. Analysis Results Demonstrating The Relationship Between The High School Students' Levels of Self-Esteem, Hopelessness and Loneliness

\begin{tabular}{|c|c|c|c|c|}
\hline & & Level of Self-Esteem & Level of Loneliness & Level of Hopelessness \\
\hline \multirow[t]{3}{*}{ Level of Self-Esteem } & Pearson Correlation & 1 &,$- 438(* \star)$ &,$- 495(* *)$ \\
\hline & Sig. (2-tailed) & &, 000 &, 000 \\
\hline & $\mathrm{N}$ & 403 & 403 & 403 \\
\hline \multirow[t]{3}{*}{ Level of Loneliness } & Pearson Correlation &,$\left.- 4388^{(\star *}\right)$ & 1 &, $369(* *)$ \\
\hline & Sig. (2-tailed) &, 000 & &, 000 \\
\hline & N & 403 & 403 & 403 \\
\hline \multirow[t]{3}{*}{ Level of Hopelessness } & Pearson Correlation &,$\left.- 4955^{(\star *}\right)$ &, $369(* *)$ & 1 \\
\hline & Sig. (2-tailed) &, 000 &, 000 & \\
\hline & $\mathrm{N}$ & 403 & 403 & 403 \\
\hline
\end{tabular}

When Table 5 is examined, it is seen that there are significant relationships between the scales. The results in Table 5 demonstrated that there was a negative relationship between the level of self-esteem and the levels of hopelessness and loneliness. In addition, a positive relationship was found between the levels of hopelessness and loneliness $(P<.01)$.

Table 6. Results of The Anova Test Regarding The Difference Between The High School Students' Levels of Hopelessness, Loneliness and Self-Esteem With Respect to Their School Type

\begin{tabular}{|c|c|c|c|c|c|c|c|}
\hline & & Sum of Squares & Df & Mean Square & $\mathrm{F}$ & $\mathrm{P}$ & Significant Differences (Tukey) \\
\hline Level of Self-Esteem & $\begin{array}{c}\text { Between Groups } \\
\text { Within Groups } \\
\text { Total } \\
\end{array}$ & $\begin{array}{c}135,278 \\
10732,698 \\
10867,975 \\
\end{array}$ & $\begin{array}{c}3 \\
399 \\
402 \\
\end{array}$ & $\begin{array}{l}45,093 \\
26,899\end{array}$ & 1,676 & 172 & \\
\hline Level of Loneliness & $\begin{array}{c}\text { Between Groups } \\
\text { Within Groups } \\
\text { Total } \\
\end{array}$ & $\begin{array}{c}1367,267 \\
35273,805 \\
36641,072 \\
\end{array}$ & $\begin{array}{c}3 \\
399 \\
402 \\
\end{array}$ & $\begin{array}{c}455,756 \\
88,406\end{array}$ & 5,155 &, 002 & $\begin{array}{l}1-4 \\
2-4 \\
3-4\end{array}$ \\
\hline Level of Hopelessness & $\begin{array}{c}\text { Between Groups } \\
\text { Within Groups } \\
\text { Total }\end{array}$ & $\begin{array}{c}170,707 \\
6502,077 \\
6672,784\end{array}$ & $\begin{array}{c}3 \\
399 \\
402\end{array}$ & $\begin{array}{l}56,902 \\
16,296\end{array}$ & 3,492 &, 016 & $2-4$ \\
\hline
\end{tabular}

1- Regular High School, 2-Science High School, 3-Anatolian High School 4-Vocational High School for Girls

When the results presented in Table 6 are examined, it is seen that the students attending the Vocational High School for Girls had higher levels of loneliness than the students from the other school types $(P<.05, X 1-X 4=-4,095$ X2$X 4=-5,137 X 3-X 4=-3,758$ ). Similarly, in terms of the level of hopelessness, there was a significant difference between the students attending the Vocational High School for Girls and the students attending Science High School in favor of the students from the Vocational High School for Girls $(P<.05, X 2-X 4=-2,3)$

Table 7. Independent Groups t-test results Regarding The Difference Between The High School Students' Levels of Hopelessness, Loneliness and Self-Esteem With Respect to Their Gender

\begin{tabular}{|c|c|c|c|c|c|c|c|}
\hline & Gender & $\mathrm{N}$ & Mean & Std. Deviation & Std. Error Mean & $\mathrm{t}$ & $p$ \\
\hline Level of Self-Esteem & $\begin{array}{l}1 \\
2 \\
\end{array}$ & $\begin{array}{l}169 \\
234 \\
\end{array}$ & $\begin{array}{l}19,97 \\
17,83 \\
\end{array}$ & $\begin{array}{l}4,731 \\
5,345 \\
\end{array}$ & $\begin{array}{l}364 \\
, 349 \\
\end{array}$ & 4,162 & ,000 \\
\hline Level of Loneliness & $\begin{array}{l}1 \\
2\end{array}$ & $\begin{array}{l}169 \\
234\end{array}$ & $\begin{array}{l}38,71 \\
41,96\end{array}$ & $\begin{array}{l}9,193 \\
9,586\end{array}$ & $\begin{array}{l}\text { 707 } \\
\text { 627 }\end{array}$ & $-3,414$ &, 001 \\
\hline Level of Hopelessness & $\begin{array}{l}1 \\
2 \\
\end{array}$ & $\begin{array}{l}169 \\
234\end{array}$ & $\begin{array}{l}5,70 \\
6,37 \\
\end{array}$ & $\begin{array}{l}3,682 \\
4,322\end{array}$ & $\begin{array}{r}, 283 \\
, 283 \\
\end{array}$ & $-1,616$ & 107 \\
\hline
\end{tabular}

1: Male 2: Female

When Table 7 is examined, it is seen that the female students had significantly lower levels of self-esteem $(p<.05)$ and higher levels of loneliness than the male students $(p<.05)$. On the other hand, it was found out that though not significant, 
the female students had higher levels of hopelessness then the male students.

Table 8. Results of The Anova Test Regarding The Difference Between The High School Students' Levels of Hopelessness, Loneliness and Self-Esteem With Respect to Their Class-Grades

\begin{tabular}{|cc|c|c|c|c|c|}
\hline & & Sum of Squares & Df & Mean Square & F & P \\
\hline Level of Self-Esteem & Between Groups & 46,876 & 2 & 23,438 &, 866 &, 421 \\
& Within Groups & 10821,099 & 400 & 27,053 & & \\
& Total & 10867,975 & 402 & & \\
Level of Loneliness & Between Groups & 202,413 & 2 & 101,206 & 1,111 &, 330 \\
& Within Groups & 36438,659 & 400 & 91,097 & & \\
& Total & 36641,072 & 402 & & \\
Level of Hopelessness & Between Groups & 21,348 & 2 & 10,674 &, 642 &, 527 \\
& Within Groups & 6651,436 & 400 & 16,629 & & \\
& Total & 6672,784 & 402 & & & \\
\hline
\end{tabular}

The results presented in Table 8 demonstrated that the adolescent students' class-grades did not cause any difference between their levels of hopelessness, loneliness and self-esteem.

Table 9. Results of The Anova test regarding The Difference Between The High School Students' Levels of hopelessness, Loneliness and Self-Esteem With Respect to the Variable of the Mother's Educational Background

\begin{tabular}{|c|c|c|c|c|c|c|}
\hline & & Sum of Squares & Df & Mean Square & $F$ & $P$ \\
\hline Level of Self-Esteem & Between Groups & 204,205 & 4 & 51,051 & 1,905 &, 109 \\
& Within Groups & 10663,770 & 398 & 26,793 & & \\
& Total & 10867,975 & 402 & & \\
Level of Loneliness & Between Groups & 459,662 & 4 & 114,915 & 1,264 &, 284 \\
& Within Groups & 36181,410 & 398 & 90,908 & & \\
& Total & 36641,072 & 402 & & \multirow{3}{*}{1,796} \\
Level of Hopelessness & Between Groups & 118,306 & 4 & 29,576 & \\
& Within Groups & 6554,478 & 398 & 16,469 & & \\
& Total & 6672,784 & 402 & & & \\
& & & & &
\end{tabular}

When Table 9 is examined, it is seen that the educational backgrounds of the students' mothers did not cause any significant difference between the adolescent students' levels of hopelessness, loneliness and self-esteem ( $p>05$ ).

Table 10. Results of The Anova Test Regarding The Difference Between The High School Students' Levels of Hopelessness, Loneliness and Self-Esteem With Respect to The Variable of The Father's Educational Background

\begin{tabular}{|c|c|c|c|c|c|c|}
\hline & & Sum of Squares & Df & Mean Square & $F$ & P \\
\hline Level of Self-Esteem & Between Groups & 97,465 & 4 & 24,366 &, 900 &, 464 \\
& Within Groups & 10770,511 & 398 & 27,062 & & \\
& Total & 10867,975 & 402 & & \\
Level of Loneliness & Between Groups & 496,725 & 4 & 124,181 & 1,367 &, 245 \\
& Within Groups & 36144,347 & 398 & 90,815 & & \\
& Total & 36641,072 & 402 & & \\
& Between Groups & 67,764 & 4 & 16,941 & 1,021 &, 396 \\
& Within Groups & 6605,020 & 398 & 16,596 & & \\
\hline
\end{tabular}

The results in Table 10 demonstrated that the educational backgrounds of the students' fathers did not cause any significant difference between the adolescent students' levels of hopelessness, loneliness and self-esteem ( $p>05$ ). 
Table 11. Results of The Anova test Regarding The Difference Between The High School Students' Levels of Hopelessness, Loneliness and Self-Esteem With Respect to The Variable of Their Ages

\begin{tabular}{|cc|c|c|c|c|c|}
\hline & & Sum of Squares & Df & Mean Square & F & P \\
\hline Level of Self-Esteem & Between Groups & 41,042 & 3 & 13,681 &, 504 &, 680 \\
& Within Groups & 10826,933 & 399 & 27,135 & & \\
& Total & 10867,975 & 402 & & \\
Level of Loneliness & Between Groups & 2,828 & 3 &, 943 &, 010 &, 999 \\
& Within Groups & 36638,244 & 399 & 91,825 & & \\
& Total & 36641,072 & 402 & & \multirow{2}{*}{, 570} \\
& Between Groups & 33,501 & 3 & 11,167 &, 671 & \\
& Within Groups & 6639,284 & 399 & 16,640 & & \\
\hline
\end{tabular}

When Table 11 is examined, it is seen that the variable of the participants' ages did not cause any significant difference between the adolescent students' levels of hopelessness, loneliness and self-esteem ( $p>05)$.

Table 12. Results of The Anova Test Regarding The Difference Between The High School Students' Levels of Hopelessness, Loneliness and Self-Esteem With Respect to The Variable of the Monthly Family Income

\begin{tabular}{|c|c|c|c|c|c|c|c|}
\hline & & Sum of Squares & $\mathrm{Df}$ & Mean Square & $\mathrm{F}$ & $P$ & Significant Differences (Tukey) \\
\hline \multirow[t]{2}{*}{ Level of Self-Esteem } & Between Groups & 320,013 & 4 & \multirow{2}{*}{$\begin{array}{l}80,003 \\
26,502\end{array}$} & \multirow[t]{2}{*}{3,019} & ,018 & \multirow[t]{2}{*}{$1-4$} \\
\hline & Within Groups & 10547,962 & 398 & & & & \\
\hline \multirow[b]{2}{*}{ Level of Loneliness } & Total & 10867,975 & 402 & \multirow[b]{2}{*}{$\begin{array}{c}364,504 \\
88,400\end{array}$} & \multirow[b]{2}{*}{4,123} & \multirow[b]{2}{*}{, 003} & \multirow[b]{2}{*}{$1-3$} \\
\hline & $\begin{array}{c}\text { Between Groups } \\
\text { Within Groups } \\
\text { Total }\end{array}$ & $\begin{array}{c}1458,014 \\
35183,058 \\
36641,072\end{array}$ & $\begin{array}{c}4 \\
398 \\
402\end{array}$ & & & & \\
\hline Level of Hopelessness & $\begin{array}{c}\text { Between Groups } \\
\text { Within Groups } \\
\text { Total }\end{array}$ & $\begin{array}{c}220,102 \\
6452,682 \\
6672,784\end{array}$ & \begin{tabular}{|c|}
4 \\
398 \\
402 \\
\end{tabular} & $\begin{array}{l}55,025 \\
16,213\end{array}$ & 3,394 & ,010 & $\begin{array}{l}1-4 \\
2-4\end{array}$ \\
\hline
\end{tabular}

1- Minimum Living Wage (658TIs) and below 2- Minimum Living wage - 1000TLs 3- 1000-2000TLs 4- 20003000TLS 5-3000TLs and over.

When the results presented in Table 12 are examined, it is seen that the students with the family income ranging between 2000-3000 TLs had higher levels of self-esteem than the students with the lowest family income (X1-X4=-3,345, $P<.05)$. In addition, the students with the lowest family income had higher levels of loneliness than those with the family income ranging between 1000-2000 TLs $(X 1-X 3=3,974, P<.05)$. Also, the students with the lowest family income and those with the family income ranging between the minimum living wage and 1000 TLs had higher levels of hopelessness than the students with the family income of 2000-3000 TLs ( X1-X4=3,111, X2-X4=2,504, $P<.05$ ).

\section{Discussion}

When the data collected at the end of the study were analyzed, a majority of the high school students who were in the period of adolescence had a normal level of self-esteem, while a considerable number of the participating students had a low level of self-esteem and only a few of them had a high level of self-esteem. When the adolescents' levels of loneliness were examined, it was seen that a substantial number of the participating students had higher loneliness scores than the mean loneliness score. Similarly, when the adolescents' levels of loneliness were examined, it was seen that the participating students had different levels of hopelessness and that a majority of them were slightly, moderately or intensely hopeless. It could be stated that there were a few students who had a moderate level of hopelessness. As adolescent students are in a period of difficult times, the problems, conflicts and adaptation problems some adolescent students experience are likely to influence such important psychological states negatively as self-esteem, loneliness and hopelessness. In addition, it is thought that environmental factors are also considered to be important. This result was not surprising at all especially considering the region where the present study was conducted. The area (it is in south east of Turkey) of the study was conducted have some economic, political and social problems for many years. Such factors as 
lack of social and cultural activities and lack of political consistency are considered likely to influence psychological development of adolescent individuals.

When studies in related literature are examined, it is seen that there are a number of studies investigating adolescents' levels of self-esteem, hopelessness and loneliness (Tajvidi \& Zeighami, 2012; Karataş \& Savi Çakar, 2011; Ruchkin, et. al., 1999; Seginer et. al., 2004). In addition, when the relationship between the adolescent students' levels of self-esteem, loneliness and hopelessness was examined, a striking result was found. The adolescent students' levels of loneliness increased in parallel to their levels of hopelessness, while these two variables and the variable of self-esteem were in negative relationship. Depending on this result, it could be stated that a student with the feeling of loneliness will have a high level of hopelessness; that he or she will have a positive viewpoint about himself or herself; and that there will be a decrease in his or her satisfaction. This result is consistent with those obtained in certain other studies reported in related literature. According to Sullivan (1953), self-esteem is important for individuals who are aware of being evaluated by others. Therefore, they try not to lose it and make effort to protect themselves against the negative psychological results of losing it. Individuals who do not have any problems with their interactions and communication with others will have an increased level of self-esteem, and the positive perception of the self will cause them not to feel any deficiencies in their social relationships. Studies conducted demonstrate that the level of loneliness has a negative relationship with the levels of negative self-perception, adaptability and social skills (Jones, Freemon and Goswick, 1981; Bilgen, 1989). For example, in one study, Koçak (2008) found out that there is a negative relationship between adolescents' levels of self-esteem and loneliness. Similarly, in another study carried out with 495 students, Al Khatib (2012) reported that students with the feeling of loneliness have a low level of self-esteem. Karataş and Savi Çakar (2011) carried out a study with 223 high school students to examine their levels of self-esteem and hopelessness. In the study, the researchers found a negative relationship between the participating high school students' levels of hopelessness and self-esteem. As a support to this finding, Thomas and Rudd (1996) examined the relationship between Ioneliness, hopelessness and suicide. As a result of their study, the researchers found a positive relationship between the levels of loneliness and hopelessness as expected. Lasgaard \& Elklit (2009) and Mahon et. al. (2006), in their study, found out that there is a negative relationship between the levels of self-esteem and loneliness. In the period of adolescence, which is difficult, complex and problematic for individuals, it is possible to experience psychological problems. Therefore, it should not be surprising that similar results were obtained in studies conducted (Dhal et.al., 2007; Durak, 2008). What is important for this period is that the individual should pass through the adulthood period with the least damage both for the adolescent himself and for his or her environment.

When the findings obtained regarding the demographic backgrounds of the participants in the study were taken into consideration, the type of the schools the participating students attended caused differences between their levels of self-esteem, hopelessness and loneliness. Depending on the findings, it could be stated that the students attending the Vocational High School for Girls felt themselves lonelier than the students from the Science High School, Anatolian High School and Regular High School. In addition, it was seen that the students from the Vocational High School for Girls had higher hopelessness scores than those attending Science High School. Based on these findings, it could be stated that the students attending Vocational High School for Girls were generally lonelier and more hopeless than the male students. Today, it could generally be stated that parents or students who fail in the placement test to get the right to attend any other type of high school prefer vocational high schools for girls for vocational education. The most important reason for especially parents' preference of this type of school is that only female students can attend these schools. On the other hand, when these students graduate from these schools, they experience difficulty achieving the placement test for higher education and most possibly fail to find a good job. "As a result of discrimination between students in terms of their traditional gender roles, vocational education reinforces social gender roles. Students can not develop their skills except these roles. This situation demonstrates that one of the most important promises of vocational education is not achieved" (Gökşen et. al., 2011). As mentioned before, in feudal regions where the present study was conducted, it is an expected and understandable situation that students attending vocational high schools for girls feel themselves psychologically lonely and hopeless. This finding is thought to be important. In relation to this, Stein and her colleagues (2012) claim in their study with Latin adolescents that cultural stress factors are important factors that cause adolescents to develop depression and hopelessness. It is important for the future of developing countries that there should not be any gender discrimination and that all students should take education in equal conditions and with equal opportunities. In addition, parallel to this finding, when all the study group students' levels of hopelessness, loneliness and self-esteem were examined with respect to their gender, it was found out that the female students had higher levels of loneliness and lower levels of self-esteem than the male students. The most important factor that influences this result regarding female students is the position of women in the social structure. Communities in certain regions in Turkey generally have a patriarchal system. In such systems, there is gender discrimination, and women are generally considered to have the 
second place and take a limited part in social life. Although the number of female students has increased due to various campaigns, women are likely to be exposed to cruel treatment and pressure. In this respect, it is an expected situation that female students may have lower levels self-esteem and higher levels of loneliness than male students. When the related literature is examined, it is seen that there are various findings supporting this result. In one study carried out in a college in the United Arab Emirates, Al Khatib (2012) compared female students' levels of self-esteem and loneliness with male students' levels of self-esteem and loneliness. As a result of the study, it was found out that the female students had lower levels of self-esteem and higher levels of loneliness than the male students. Yaacob, Juhari, Abu Talib and Uba (2009) reported in their study with adolescent students in Malaysia that the female students had lower levels of self-esteem and higher levels of loneliness than the male students. Similarly, in a number of studies conducted (Kling, Hyde, Showers \& Buswell, 1999; Mahmoudi, 2011; Tamini and Valibeygi, 2011; Robins et al., 2002), men in the period of adolescence had higher levels of self-esteem than women in this period. In addition, in another study, Kutlu (2003) pointed out that female students in the period of adolescence feel themselves lonelier than male students. On the other hand, Balat and Akman (2004) reported that gender does not have any influence on self-esteem, and Gürsoy and Bıçakçı (2006) pointed out that it does not have an effect on the level of loneliness. In contrast with these findings obtained in the study, there are other findings reported in related literature that men have higher levels of loneliness than women (Avery, 1982; Stokes \& Levin, 1986). Although there are various findings reported in literature, the findings obtained in this study are thought to be consistent with the feudal structure of the region which is quite bad for the place of women in the society - where the present study was conducted. Cultural stressors have an important role in the development of an individual's self-esteem (Abramson, Metalsky, \& Alloy, 1989; Garber, Robinson, \& Valentiner, 1997). Due to the patriarchal structure of the region where the study was carried out, it could be stated that there occur more factors causing pressure on women. In addition, the present study examined whether the adolescent students' levels of self-esteem, hopelessness and loneliness differed with respect to their class-grades, ages, their parents' educational backgrounds and socio-economic class. As a result of the analyses conducted, it was found out that the participating students' levels of self-esteem, hopelessness and loneliness did not significantly differ with respect to their class-grades, ages, number of their siblings or their parents' educational backgrounds yet differed depending on their socio-economic levels. It was seen that the participating students' levels of self-esteem, loneliness and hopelessness decreased as their parents' financial state improved. This study included the students who were in the period of adolescence. Students struggle with the problems of the period of adolescence just like their friends regardless of their class-grades or ages. Therefore, the class-grades and ages of adolescents may not be expected to have any influence on certain affective domains in this period. In addition, the similar educational backgrounds of the parents might have influenced the results obtained in the present study. In addition, when the number of the siblings of the participants was taken into consideration, it was seen that the average number of the siblings was already high and that the participants were members of crowded families. Thus, the influence of the number of the siblings on the participants' levels of self-esteem, hopelessness and loneliness can not be predicted. When the studies in literature were examined, it was seen that there were similar results and various findings regarding the influence of these factors. Xiao and Daniel (2012) investigated the relationship of high school students' levels of hopelessness with their socio-demographic backgrounds and family-related variables in Shanghai. The results of the study revealed that the adolescents' levels of hopelessness had a positive relationship with their ages. In addition, the researchers reported that parents' educational backgrounds and financial disadvantages influence adolescent students' levels of hopelessness. For example, Şengül and Güner (2012) found out that there was no difference in the students' levels of hopelessness in terms of their class-grades, and Ürün (2010) reported no difference in the students' levels of self-esteem in terms of their class-grades. Different from the findings obtained in the present study, Özmen and her colleagues (2008) demonstrated that adolescent students' levels of hopelessness decrease in line with their parents' educational backgrounds. On the other hand, Buluş (2000) reported that there was no difference between the fathers' educational backgrounds and the adolescent students' levels of loneliness; that the adolescent students' levels of loneliness decreased as their mothers' education levels increased; and that the adolescent students felt themselves lonelier parallel to the number of their siblings. In addition, Duyan and his colleagues (2008) found out that the students whose parents were university graduates had lower levels of loneliness and that those with a higher number of siblings had higher levels of loneliness. Similar to the findings obtained in this study, another study carried out by Tan (2000) revealed that the fathers' educational backgrounds and the adolescents' class-grades influenced their levels of loneliness. In another study, Eren (1994) reported that the effects of class-grade, age, number of siblings and parents' educational backgrounds on the level of loneliness were not significant. Öztürk and her colleagues (2006), in their study, did not find any significant difference between the mean loneliness scores and the participants' class-grades, their departments, their ages and their fathers' educational backgrounds. Similarly, in another study conducted by Çiftçi Uruk and Ayhan (2003), it was found out that adolescents' levels of loneliness were not influenced by 
their number of siblings or by their parents' educational backgrounds. As a support to the findings obtained in the present study, Özogul (1988) reported that the mothers' educational backgrounds did not have any significant influence on selfesteem. In one study, Özkan (1994) demonstrated that the parents' educational backgrounds influenced the adolescent students' levels of self-esteem positively. Another study carried out by Gür (1996) revealed that the mothers' educational backgrounds and the number of siblings were significant predictors of adolescents' levels of self-esteem. Balat and Akman (2004) and Güngör (1986) reported in their studies with high school students that the adolescents' ages did not have any influence on their levels of self-esteem. In another study conducted by Tamini and Valibeygi (2011), it was found out that the adolescent students' ages did not influence their levels of self-esteem. In a comprehensive review of literature, Wylie (1979) reported that age does not influence self-esteem systematically. In this respect, as a result of the review of the related literature in the present study, it was seen that different results were obtained regarding the influence of the demographic factors in question.

However, similar to the results obtained in the present study, there are a number of findings in related literature regarding families' financial states and adolescent students' levels of self-esteem, hopelessness and loneliness. For instance, Özmen et.al. (2008) found out that students' levels of hopelessness decreased as the family income increased. In a similar study, Üngüren and Ehtiyar (2009) examined Turkish and German students' levels of hopelessness. The researchers reported that Turkish students' levels of hopelessness differed between those with low levels of family income and those with high levels of income. It was found out that the students with the high levels of family income had lower levels of hopelessness than those with low levels of family income. In addition, it was also reported in the same study that German students' levels of hopelessness were not influenced by their levels of family income. Xue et. al. (2005) stated that individuals with low levels of family income were more inclined to such psychological problems as depression. Gürsoy and Bıçakçı (2006), in their study, found out that adolescents with high levels of family income had low levels of loneliness. Another study carried out by Le Roux (2009) revealed that students with low levels of family income were more inclined to loneliness than those with high levels of family income. Similarly, Duyan and his colleagues (2008) reported that high school students' levels of loneliness had a negative relationship with the level of family income. The researcher found out that the students with high levels of family income had lower levels of loneliness. In another study conducted by Özkan (1994), it was revealed that there was a positive relationship between the level of self-esteem and the level of family income. In contrast with this finding, Balat and Akman (2004) demonstrated that there was no significant relationship between high school students' levels of self-esteem and their socio-economic levels. As can be seen in a number of studies, financial welfare could help adolescent students feel themselves in comfort in certain psycho-social aspects. Adolescent students who have financial difficulties and who thus feel embarrassed among their friends and feel casted out by their friends are likely to feel themselves lonely and hopeless and to lack self-confidence. As a result, they are also likely to have negative feelings and thoughts about themselves. It was seen in general that as expected, the findings reported in related literature are consistent with those obtained in the present study (Güngör, 1986; Özoğul, 1988; Güçray, 1989).

\section{Conclusions and Suggestions}

The analyses conducted and the findings obtained in the present study revealed that a majority of the adolescent students had normal level of self-esteem; that a considerable number of them had low levels of self-esteem; and that only a few of them had high levels of self-esteem. In addition, it was seen that the participating adolescent students' levels of loneliness, though not many in number, were higher than the mean score. Similarly, when the hopelessness scores were taken into consideration, a considerable number of students were found to be inclined to hopelessness. Depending on these findings, it is suggested that these students, who have to struggle with various difficulties and problems during the period of adolescence, should be provided with psychological support both at schools and in various social units. It is important for the future of societies and countries if adolescent students hold on to life to get over this period with the least damage. In this respect, parents should support these individuals with great care and understanding, and authorities concerned should give efficient psychological counseling services to the region where the present study was conducted.

As a result of the present study, no other factor (class-grade, age, number of siblings and parents' educational backgrounds) influencing the adolescent students' levels of hopelessness, loneliness and self-esteem except for such variables as gender, school type and the family income were determined. In the present study, it was a striking finding that especially the female students had lower levels of self-esteem and higher levels of loneliness than the male students. When this finding and the feudal structure of the region where the study was conducted are taken into consideration together, the finding obtained is not surprising at all. However, considering the universal conditions, this is obviously a negative situation in terms of women's rights and problems. Therefore, it is important to examine the living conditions of 
women in this region and to conduct studies evaluating their psycho-social situations. In the light of the findings obtained in the present study and of those to be obtained in other similar studies, governmental or non-governmental institutions should hold several seminars and organizations to raise parents and individuals' consciousness so that the situation can be improved for women and for the society in the region.

The present study revealed that some of the students with low levels of family income had lower levels of selfesteem, loneliness and hopelessness than the other students. In order for these students to become healthier individuals, institutions and ministries concerned should support them during their school lives as it should be in a social state.

For the generalization of the results obtained in the present study, it should be replicated with a larger group of adolescent students not only on national but also on international basis.

\section{References}

Abdi, F., \& Bagheri, F. (2012). Relationship between Identity and Self-esteem with Attitude to life among Art Students. Advances in Environmental Biology, 6(4), 1364-1369.

Abramson, L., Metalsky, G., \& Alloy, L. (1989). Hopelessness depression: Atheory-based subtype of depression. Psychological Review, 96, 358-372.

Al Khatib, S. A. (2012). Exploring the Relationship among Loneliness, Self-esteem, Self-efficacy and Gender in United Arab Emirates College Students, Europe's Journal of Psychology, 8(1),159-181

Avery, A. W. (1982). Escaping loneliness in adolescence: The case for androgyny. Journal of Youth and Adolescence, 11, 451459.

Balat G.U., \& Akman B.(2004). Farkı Sosyo-Ekonomik Düzeydeki Lise Öğrencilerinin Benlik Saygısı Düzeylerinin İncelenmesi. Fırat Üniversitesi Sosyal Bilimler Dergisi. 14(2),175-183.

Batigün Durak, A (2008). Intihar Olasiligi ve Cinsiyet: lletisim Becerileri, Yasami Sürdürme Nedenleri, Yalnizlik ve Umutsuzluk Açisindan Bir Inceleme. Türk Psikoloji Dergisi , 23(62 ), 65-78.

Beck, A. T., Weissman, A., Lester, D., \& Trexler, L. (1974). The Hopelessness Scale. Journal of Consulting and Clinical Psychology, 42(6), 861-865.

Beck, A. T., \& Steer, R. A. (1988). Manual for the Beck Hopelessness Scale. San Antonio, TX: Psychological Corp.

Benas, J., \& Gibb, B. (2007). Peer victimization and depressive symptoms: The role of body dissatisfaction and self-esteem. Journal of Cognitive Psychotherapy, 21(2), 107-116.

Bilgen, S. (1989). Üniversite Öğrencilerinin Yalnızlık düzeyleri ve Bazı Değişkenlerin Uyum Düzeylerine Etkisi. Yayınlanmamış Yüksek Lisans Tezi, Hacettepe Üniversitesi, Ankara.

Bolland, J. M., McCallum, D. M., Lian, B., Bailey, C. J., \& Rowan, P. (2001). Hopelessness and violence among inner-city youths. Maternal and Child Health Journal, 5(4), 237-244

Buluş, M. (2000). Öğretmen adaylarında yükleme karmaşıklığı, düşünme stilleri ve bilişsel tutarlıık tercihinin bazı psikososyal özellikler ve akademik başarı çerçevesinde incelenmesi. Dokuz Eylül Üniversitesi Eğitim Bilimleri Enstitüsü Rehberlik ve Psikolojik Danışma Anabilim Dalı. Doktora Tezi.

Ceylan, R., \& Aral.,N. (2007). An examination of the correlation between depression and hopelessness levels in mothers of disabled children. Social Behavior and Personality, 35, 903-908.

Ciftci Uruk, A., \& Demir, A. (2003). The role of peers and families in predicting the loneliness level of adolescents. The Journal of Psychology, 137(2), 179-193.

Chubb, N.H., Fertman, C. I., \& Ross, J.L. (1997). Adolescent Self-Esteem and Locus of Control: A Longidutinal Study of Gender and Age Differencies. Adolescence, 32(125), 113-129.

Coleman, J., \& Hendry, L.( 1990) .The Nature of Adolescence. Second Edition, London: Routledge.

Çeçen, A.R. (2008). Üniversite Örgencilerinde Yasam Doyumunu Yordamada Bireysel Bütünlük (Tutarlıık) Duygusu, Aile Bütünlük Duygusu ve Benlik Saygısı, Eğitimde Kuram ve Uygulama,4 (1),19-30.

Çuhadaroğlu, F. (1986). Adölesanlarda benlik saygısı. Uzmanlık Tezi. Hacettepe Üniversitesi Tıp Fakültesi Psikiyatri AD., Ankara.

Demir, A. (1989). UCLA yalnızlık ölçeğinin geçerlik ve güvenirliği. Psikoloji Dergisi, 7(23),14-28.

Dhal,A., Bhatia,S., Sharma,V., \& Gupta, P. (2007). Adolescent Self-Esteem, Attachment and Loneliness J. Indian Assoc. Child Adolesc. Ment. Health, 3(3),61-63.

Durak, A. (1994). Beck Umutsuzluk Ölçeğinin Geçerlik ve Güvenirlik Çalışması. Türk Psikoloji Dergisi, 9 (31), 1-11.

Duyan, V., Çamur Duyan, G., Gökçearslan Çifçi, E., Sevin, Ç., Erbay,E., \& İkizoğlu, M. (2008). An Examination of Variables Affecting State of Loneliness in High School Students. Education and Science , 33 (150), 28-41.

Eccless, J.S., Midgley, C., Wigfield, A. Buchanan, C. M. , Reuman, D., Flanagan, C., \& Maclver, D. (1993). Development During Adolescence, The Impact of Stage Environment Fit on Young Adolescents' Experiences in Schools and in Families, American Psychologist, 48(2), 90-101.

Eren, A. (1994). Lise öğrencilerinin yalnızlık düzeyleri ve psikolojik ihtiyaçlarının incelenmesi. Yayımlanmamış yüksek lisans tezi, Gazi Üniversitesi Sosyal Bilimler Enstitüsü, Ankara.

Erözkan, A. (2009).The Predictors of Loneliness in Adolescents. Elementary Education Online, 8(3), 809-819, 2009.

Erözkan, A. (2011). The attachment styles bases of loneliness and Depression. International Journal of Psychology and Counselling, 
3(9), 186-193.

Erözkan, A.(2011). Investigation of Factors Predicting the Anxiety Level of University Senior Students, International Online Journal of Educational Sciences, 3(2), 776-805

Eskin, M. (2001). Ergenlikte Yalnızlık, Başetme Yöntemleri ve Yalnızlığın İntihar Davranışı ile İlişkisi. Klinik Psikiyatri, 4,5-11.

Frisen, A. (2007). Measuring health-related quality of life in adolescence. Acta Paediatrica, 96(7), 963-968.

Garber, J., Robinson, N., \& Valentiner, D. (1997). The relation betweren parenting and adolescent depression: Self-worth as a mediator. Journal of Adolescent Research, 12(1), 12-33.

Goodwin, R., Cook O., \& Yung, Y. (2001). Loneliness and life satisfaction among three cultural groups. Personal Relationships, 8 (2), 225-230.

Gökşen, F., Yükseker, D., Alnıaçık, A., \& Zenginobuz, Ü. (2011). Kız teknik ve meslek liseleri kapsamlı değerlendirme notu. Eğitim Reformu Girişimi, İstanbul.

Güçray, S. (1989). Çocuk Yuvasında ve aile yanında kalan 9-10-11 yaş çocuklarının özsaygı gelişimini etkileyen bazı etkenler. Yayınlanmamış Doktora Tezi, Ankara.

Güngör, A. (1989). Lise Öğrencilerinin Öz saygı Düzeyini Etkileyen Etmenler. Yayınlanmamış Doktora Tezi, Hacettepe Üniversitesi, Ankara

Gürsoy, F., \& Yıldız Bıçakçı, M. (2006). A study on the lonelıness level of adolescents. Journal of Qafqaz University, 140-146.

Han, X. Y., \& Shek, D. T.L. (2012). Socio-demographic and family correlates of hopelessness among adolescents in Shanghai, China. International Journal on Disability and Human Development. 11(2), 113-119.

Joiner, T. E.Jr., \& Rudd, D. M. (1996). Disentangling the interrelations between hopelessness, loneliness, and suicidal ideation. Suicide \& Life - Threatening Behavior ,26 (1), 19-26.

Jones, W.H., Freemon, J.E., \& Goswick, R.A. (1981). The Persistence of Loneliness: Self and Other Determinants, Journal of Personality, 49,27-28.

Kapıkıran, Ş., \& Yağcı, Y. (2012). Loneliness and life satisfaction of adolescents: the mediator and moderator role of playing musical Instruments and joining a band. Elementary Education Online, 11(3), 738-747.

Karataş, Z. \& Savi Çakar, S. (2011). Self-Esteem and Hopelessness, and Resiliency: An Exploratory Study of Adolescents in Turkey. International Education Studies, 4(4), 84-91.

Kling, K. C., Hyde, J. S., Showers, C. J., \& Buswell, B. N. (1999). Gender differences in self-esteem: A meta-analysis [Electronic version]. Psychological Bulletin, 125, 470-500.

Koçak , E. (2008), Ergenlerde yalnızlığın yordayıcısı olarak benlik saygısı ve sürekli öfke ve öfke ifade tarzlarının incelenmesi, Çukurova Üniversitesi Sosyal Bilimler Enstitüsü.

Kutlu, M. (2003). Yetiştirme Yurdunda ve Ailesiyle Birlikte Kalan Öğrencilerin Yalnızlık Düzeylerinin Çeşitli Değişkenlere Göre İncelenmesi. İnönü Üniversitesi 9-11 Temmuz VII. Ulusal Psikoloji ve Rehberlik Danışma Kongresi Bildiri Özetleri Kitabı s. 11. (editör. H.Atılgan ve M. Saçkes) Ankara: Pegem Yayıncılık.

Lai-Kwok, S. Y. C., \& Shek, D. T. L. (2010). Hopelessness, parent-adolescent communication, and suicidal ideation among Chinese adolescents in Hong Kong. Suicide and Life-Threatening Behavior, 40(3), 224-233.

Lasgaard, M., \& Elklit, A. (2009). Prototypic features of loneliness in a stratified sample of adolescents. Interpersona, 3(1), 85-110.

Le Roux, A., \& Connors, J. (2001). A cross-cultural study into loneliness amongst university students. South African Journal of Psychology, 31, 46-52.

Le Roux, A. (2009). The Relationship Between Adolescents' Attitudes Toward Their Fathers and Loneliness: A Cross-Cultural Study. J Child Fam Stud, 18, 219-22.

Mahmoudi, A. (2011). Influences gender on adjustment and self-esteem among adolescents. IJEMR,1(7),1-5.

Mahon, N. E., Yarcheski, A., Yarcheski, T. J., Cannella, B. L., \& Hanks, M. M. (2006). A meta-analysis of predictors of loneliness during adolescence. Nursing Research, 55, 308-315.

Moore D., \& Schultz NR (1983). Loneliness at adolescence: correlates, attributions, and coping. J Youth and Adolescense, 12, 95-100.

Nordin, N., Md, Abu Talib,M., \& Yaacob,S.,N. (2009). Personality, Loneliness and Mental Health Among Undergraduates at Malaysian Universities. European Journal of Scientific Research, 36(2), 285-298.

Özkan, İ. (1994). Benlik Saygısını Etkileyen Etkenler. Düşünen Adam, 7 (3), 4-9.

Özoğul, S. N. (1988). Annenin çalışmasının ve bazı bireysel niteliklerin çocuğun özsaygısına etkisi. Yayınlanmamış Yüksek Lisans Tezi, Hacettepe Üniversitesi.

Özmen, D., Erbay Dündar, P., Çetinkaya, A., Taşkın, O., \& Özmen, E. (2008). Hopelessness and factors affecting hopelessness in high school students. Anatolian Journal of Psychiatry, 9,8-15.

Öztürk, H., Nazik Sevindik,F., \& Yaman, S. Ç. (2006). The assesment loneliness and social support and these influencing some agents at students. University Journal of Social Science, 16(1), 383-394.

Peplau, L. A., \& Perlman, D. (1982). Perspectives on loneliness. In L. A. Peplau \& D. Perlman (Eds.), Loneliness: A sourcebook of current theory, research and therapy (p. 21-39). New York: Wiley.

Robins, R. W., Trzesniewski, K. H., Tracy, J. L., Gosling, S. D., \& Potter, J. (2002). Global selfesteem across the life span. Psychology and Aging, 17, 423-434.

Rosenberg, M. (1965). Society and Adolescent Self-Image, Princeton, New Jersey: Princeton University Press.

Rutter, P. A., \& Behrendt, A.E. (2004). Adolescent Suicide Risk: Four Psychosocial Factors. Adolescence, 39(154), $295-302$.

Ruchkin, V. V., Eisemann, M., \& Hägglöf, B. (1999). Hopelessness, Loneliness, Self-Esteem, and Personality in Russian Male 
Delinquent Adolescents versus Controls. Journal of Adolescent Research,14, 466-477.

Russell, D., Peplau, L.A., \& Ferguson, M.L. (1978). Developing a measure of loneliness. Journal of Personality Assessment, 42, 290294.

Russell, D., Peplau, L. A., \& Cutrona, C. E. (1980). The Revised UCLA Loneliness Scale: Concurrent and Discriminant Validity Evidence. J Pers Soc Psy, 39, 472-480.

Salami, S.O. (2010). Moderating effects of resilience, self-esteem and social support on adolescents' reactions to violence. Asian Social Science, 6(12), 101-110.

Seginer, R., \& Lilach, E. (2004). How adolescents constructs their future: the effect of loneliness on future orientation. Journal of Adolescence, 27(6), 625-643.

Stein, G.L., Gonzalez, L.M., \& Huq, N. (2012). Cultural Stressors and the Hopelessness Model of Depressive Symptoms in Latino Adolescents. J Youth Adolescence, 41,1339-1349.

Stokes, J., \& Levin, I. (1986). Gender differences in predicting loneliness from social network characteristics. Journal of Personality and Social Psychology, 51, 1069-1074.

Sullivan, H.S. (1953). Interpersonal Theory Of Personality.New York: Norton Company Inc

Şengül, S., \& Güner, P. İlköğretim Matematik Öğretmenliği Programına Devam Eden Öğretmen Adaylarının Umutsuzluk Düzeylerinin Incelenmesi. Niğde Üniversitesi,27-30 Haziran X. Ulusal Fen ve Matematik Eğitimi Kongresi.

Tamini, B.,K., \& Valibeygi, R. (2011).The Impact of Gender, Age and Academic Branch on Self-Esteem of Students. Journal of Basic and Applied Scientific Research, 1(9), 1065-1069.

Tan, D. (2000). Lise öğrencilerinin yalnızlık düzeyleri ile denetim odaklarının ile destek düzeyleri ve özlük nitelikleri açısından karşılaştııılmalı olarak incelenmesi. Yayımlanmamış yüksek lisans tezi, Selçuk Üniversitesi, Sosyal Bilimler Enstitüsü, Konya.

Tajvidi M.1, Zeighami Mohammadi Sh (2012.) The level of loneliness, hopelessness and self-esteem in major thalassemia adolescents. Sci J Iran Blood Transfus Organ, 9(1), 36-43.

Tsai, J. L., Ying, Y., \& Lee, P. A. (2001). Cultural predictors of self-esteem: A study of Chinese American Femanle and Male Young Adults. Cultural diversity and ethnic minority psychology, 7(3), 284-297.

Üngüren, E., \& Ehtiyar, R. (2009). Comparıson of turkish and german undergraduats hopelessness level and determınatıon of the predıctors of hopelessness level: a case study on undergraduate who study in tourism. Journal of Yasar University, 4(14), 20932127

Ürün, E. (2010). Lise öğrencilerinin kendine saygı düzeyleri İle mesleki olgunlukları arasındaki ilişki. Yüksek lisans tezi, Balıkesir Üniversitesi Sosyal Bilimler Enstitüsü Eğitim Bilimleri Anabilim Dalı.

Wylie, R. C. (1979). The Self-concept. Lincoln, NE: University of Nebraska Press.

Xue,Y., Leventhal,T., Brooks-Gunn, J., \& Earls F. J. (2005) Neighborhood residence and mental health problems of 5- to 11-year-olds. Archives of Genetic Psychiatry, 62,554-563.

Yaacob, S. N., Juhari, R., Abu-Talib, M., \& Uba, I. (2009). Loneliness, stress, self-esteem and depression among Malaysian adolescents. Jurnal Kemanusiaan,14, 85-90

Yörükoğlu, A. (1998). Gençlik Çağı. (10.Basım). Özgür Yayınları: İstanbul. 